\title{
Leiomyosarcoma of the Inferior Vena Cava: A Case Report of Complete and Sustained Response with Trabectedin
}

\section{Leiomiosarcoma da Veia Cava inferior: Um Caso Clínico de Resposta Completa e Prolongada com Trabectedina}

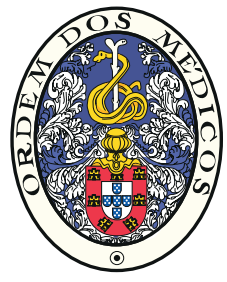

André CRUZ $\rrbracket^{1}$, Luís BRETES ${ }^{1,2}$, Carlos REIS ${ }^{1,2}$, Irene FURTADO ${ }^{1,2}$

Acta Med Port 2016 Apr;29(4):284-286 - http://dx.doi.org/10.20344/amp.7211

ABSTRACT

Inferior vena cava leiomyosarcoma is a very rare tumor, accounting for only $0.5 \%$ of all soft tissue sarcomas. As the other leyomiosarcomas of vascular origin, they have a poor prognosis, and radical resection with surgical margins free of tumor is the only potentially curative treatment. We present a case of a 46 year-old woman with metastatic inferior vena cava leiomyosarcoma who progressed after anthracyclines and ifosfamide and achieved a complete and sustained response with trabectedin. Beyond progression, the patient started third line treatment with pazopanib. A brief review of literature is also given. This case supports the efectiveness of a recent therapeutic agent, with an impressive progression-free survival in a recurrent metastatic inferior vena cava leiomyosarcoma.

Keywords: Disease-Free Survival; Leiomyosarcoma; Vena Cava, Inferior; Trabectedin.

RESUMO

O leiomiossarcoma da veia cava inferior é um tumor raro, constituindo apenas 0,5\% dos sarcomas de tecidos moles. À semelhança de outros leiomiossarcomas de origem vascular, estão associados a um mau prognóstico, sendo a ressecção com margens livres de tumor o único tratamento potencialmente curativo. Apresentamos um caso de uma doente de 46 anos com um leiomiossarcoma metastizado, refratário a antraciclinas e ifosfamida, e com resposta completa e prolongada sob trabectedina. Após progressão, a doente iniciou terapêutica de terceira linha com pazopanib. Será feita uma breve revisão da literatura. Este caso suporta a eficácia de uma terapêutica recente, demonstrando uma sobrevivência livre de progressão atípica num leiomiossarcoma metastático e refratário. Palavras-chave: Intervalo Livre de Doença; Leiomiossarcoma; Veia Cava Inferior; Trabectedina.

\section{INTRODUCTION}

The soft tissue sarcomas (STM) are a heterogeneous group of rare tumors that develop from the mesenchymal stem cells which can differentiate in several cell lines (muscle, adipose, and connective tissue). ${ }^{1}$

The leiomyosarcoma is the second most frequent histological subtype of STM (28\%) and the most common primary tumor of the inferior vena cava. However, the inferior vena cava leiomyosarcoma (IVCL) represents only $0.5 \%$ of STM, with approximately 300 cases described in literature. ${ }^{2}$

The clinical presentation is typically insidious and nonspecific, which often leads to diagnosis in advanced stage. The most common presenting symptom is pain in the right flank. ${ }^{3}$

Surgical resection, eventualy in combination with neoadjuvant and/or adjuvant treatment, is the only potentially curative therapy. However, advanced and metastatic STS have a poor prognosis. ${ }^{1}$ Effective antitumoral agents in the treatment of patients with metastatic STS are limited, especially when there is no response to conventional therapy with anthracyclines and ifosfamide. ${ }^{4}$

Trabectedin is an anti-tumoral agent originally extracted from the ascidian Ecteinascidia turbinata and currently obtained by chemical synthesis. Approved in 2007, trabectedin is indicated for the treatment of patients with advanced STM refractory to therapy with anthracyclines and ifosfamide, or if treatment with these drugs is not indicated. ${ }^{5}$ Pazopanib, a multitargeted tyrosine kinase inhibitor, was also recently approved for nonadipocytic soft tissue sarcomas refractory to chemotherapy. ${ }^{6}$

We report the case of a patient with IVCL treated with multiple anti-tumoral agents, achieving a complete and prolonged remission with trabectedin.

\section{CASE REPORT}

46-year old female, admitted in December 2010 with nonspecific abdominal pain. No relevant personal history and a physical exam without findings. An abdominal computerized tomography (CT) showed a large, well defined retroperitoneal mass, with heterogeneous contrast uptake and slightly lobulated contours in contact with the duodenum, kidney, right ureter, aorta and inferior vena cava (IVC). An exploratory laparotomy was performed, with a bloc ressection of the tumor mass without intraoperative complications. Histological and immunohistochemical analyses revealed a grade 3 leiomyosarcoma arising from the IVC, with positive margins.

Re-staging postoperative CT revealed hepatic and pulmonary metastasis. She started in 30/05/11 palliative combination chemotherapy with doxorubicin, ifosfamide,

\footnotetext{
1. Serviço de Medicina Interna. Centro Hospitalar do Algarve. Faro. Portugal.

2. Unidade de Oncologia Médica. Centro Hospitalar do Algarve. Faro. Portugal.

$\triangle$ Autor correspondente: André Cruz. andre.andraz@hotmail.com

Recebido: 17 de novembro de 2015 - Aceite: 08 de março de 2016 | Copyright @ Ordem dos Médicos 2016
} 


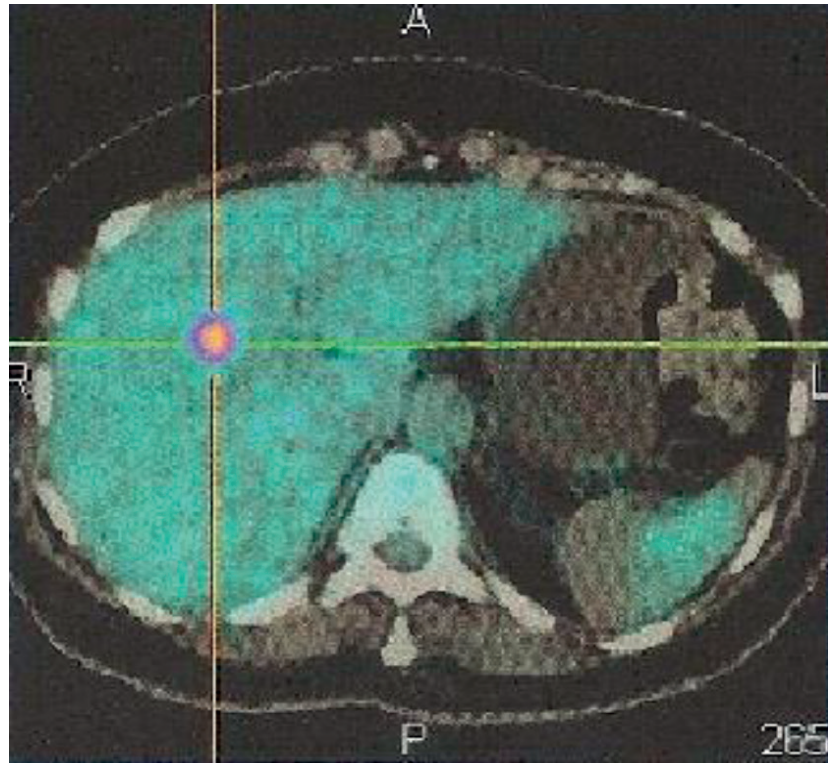

Figure 1 - Positron emission tomography - computed tomography (PET/CT) showing the second hepatic relapse after chemotherapy re-challenge, interrupted after a grade 4 renal toxicity (Fanconi syndrome)

cisplatin, a total of six cycles every three weeks. The patient achieved complete remission, both imagiologic and metabolic, with grade 3 hematologic toxicity. After thirteen months there was disease progression, with oligometastatic but unressectable disease, including one lung metastases and three liver metastases. Given the excellent response and progression-free interval, she was re-challenged with the same chemotherapy regimen. Considering the limits imposed by the cumulative dose of doxorubicin, the liposomal formulation was prefered in attempt to reduce cardiotoxicity. Cardiac evaluation regularly perfomed showed stable left ventricular function. The patient had renal toxicity at cycle 2 , with acute proximal tubular necrosis induced by ifosfamide - iatrogenic Fanconi syndrome.

With a second hepatic and pulmonar relapse (Fig. 1) and

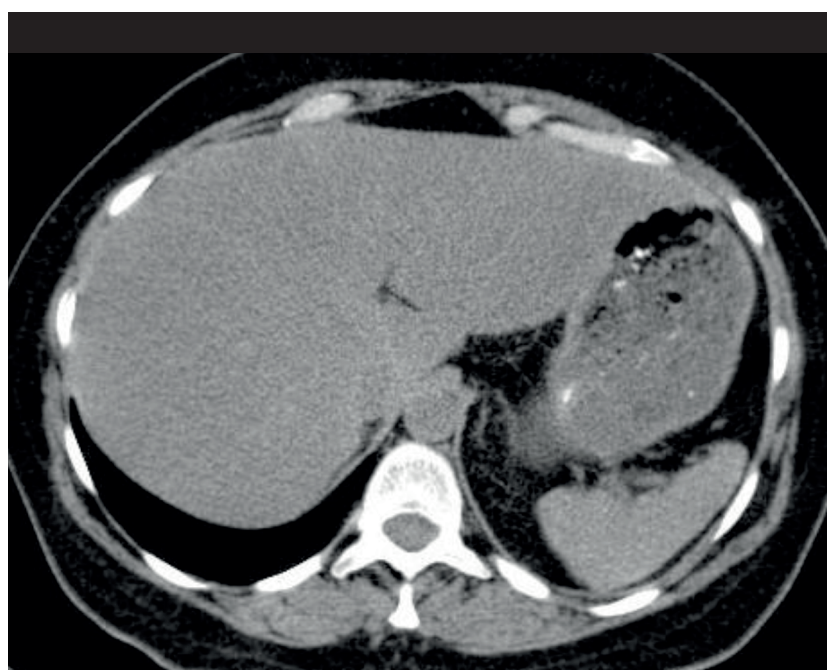

Figure 2 - Computed tomography (CT) without hepatic nodules after cycle 7 of trabectedin, when the patient achieved a complete response, both hepatic and pulmonary without possibility to continue chemotherapy with the same agents, the patient started in April 2013 second line palliative chemotherapy with trabectedin at the recommended dose of $1.5 \mathrm{mg} / \mathrm{m}^{2}$ administered as intravenous infusion over 24 hours, every 3 weeks. Considering the toxicity profile of trabectedin and the previous hematologic toxicity she recieved prophylactic granulocyt-colony stimulating factor throughout the treatment. Evaluation was perfomed every 3 cycles, with partial response at cycle 3 and complete response (imagiologic and metabolic) at cycle 7, August 2013. (Fig. 2).

The patient remained asymptomatic, only with transitory grade 1 fatigue and transaminases elevation and without evidence of disease until completing twenty one cycles of trabectedin (September 2014), time of second progression (Fig. 3) with three hepatic lesions in the segment VII (7 $\mathrm{mm})$, V segment $(10 \mathrm{~mm})$ and $\mathrm{VI}$ segment $(10 \mathrm{~mm})$.

The patient started third line treatment with Pazopanib with stable disease on the first response assessment.

\section{DISCUSSION}

Inoperable STS present mostly a poor prognosis. The median survival of these patients is $8-13$ months with anthracyclines and ifosfamide based-chemotherapy. Survival after progression with this therapy is 6 months. ${ }^{7}$

The identification of therapeutic alternative for the treatment of patients with refractory STM is essential. Trabectedin was originally isolated from the Caribbean sea sponge Ecteinascidia turbinate. It covalently binds to the minor groove of DNA to cause drug-induced DNA damage, which results in perturbations in the cell cycle and induction of apoptosis. ${ }^{8}$

The efficacy and safety of trabectedin in the treatment of STS was evaluated in a clinical trial with locally advanced and metastatic liposarcoma and leiomyosarcoma refractory to treatment with anthracyclines and ifosfamide. This trial showed a progression-free survival (PFS) of 3.3 months and an overall survival of 13.9 months in the group submitted

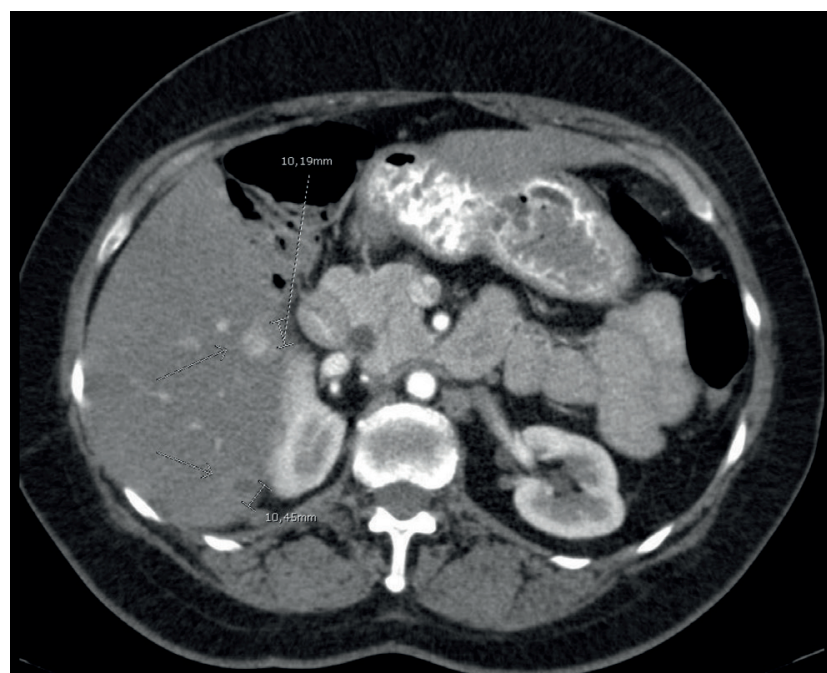

Figure 3 - Computed tomography (CT) showing hepatic recurrence after cycle 21 of trabectedin, corresponding to a near 17 months progression-free survival (PFS) 
to trabectedin, $1.5 \mathrm{mg} / \mathrm{m}^{2}$ as an intervenous infusion for 24 hours every 3 weeks. ${ }^{7}$

It presents as a valid therapeutic option for patients with STS refractory to anthracyclines and ifosfamide, specifically in IVCL subtype. ${ }^{7}$

The most common adverse reactions described in the literature include neutropenia, nausea, vomiting, elevation of transaminases, anemia, fatigue, thrombocytopenia, anorexia and diarrhoea, mostly transitory and reversible. ${ }^{9}$ In clinical trials there were no cumulative toxicity in patients treated with multiple cycles. Therefore there isn't an established limit to the number of treatment cycles with trabectedin and could be offered as long as clinical benefit is observed. A recent randomized phase II trial recommended maintenance treatment beyond six trabectedin cycles until disease progression, with good tolerability. ${ }^{10}$

More recently, a phase III trial comparing trabectedin to dacarbazine in metastatic lipossarcoma and leiomyossarcoma after chemotherapy, also favors trabectedin in terms of PFS. ${ }^{9}$ Another treatment option in this setting, pazopanib is a synthetic indazolylpyrimidine that functions as a multitargeted tyrosine kinase inhibitor (TKI) with a high affinity for vascular endothelial growth factor receptors and a low affinity for platelet-derived growth factor receptors, fibroblast growth factor receptors, and c-Kit. ${ }^{11}$ The PALETTE trial, the phase III trial that gave approval of pazopanib (800 $\mathrm{mg}$ orally once daily) for metastatic STS after failure with chemotherapy, reported a significantly prolonged PFS of 4.6 months compared to 1.6 months for placebo. The most common adverse effects were fadigue, diarrhoea, nausea, weight loss and hypertension. ${ }^{6}$

An active area of research in STS is the use of novel combinations of agents, such as chemotherapy combined with multi-targeted agents.

The potential of immune check point inhibitors is being explored in advanced STS and is hoped to further expand our treatment armamentarium. ${ }^{12}$ The patient had a very favorable tolerability, with grade 1 fatigue and transminases elevation, in agreement with the toxicity profile reported in clinical trials. Treatment with trabectedin was maintained for twenty one cycles, always with clear clinical benefit and an aproximately 17 months PFS with complete response.

The third line therapy with pazopanib was also well tolerated, with stable disease at first response evaluation. We intend to show a case of exceptional rarity and a clinical response that, although uncommon, reinforces the role of trabectedin in the treatment of STS advanced and refractory to anthracyclines and ifosfamide, specifically in the treatment of histological subtype IVCL.

\section{PROTECTION OF HUMANS AND ANIMALS}

The authors declare that the procedures were followed according to the regulations established by the Clinical Research and Ethics Committee and to the Helsinki Declaration of the World Medical Association.

\section{DATA CONFIDENTIALITY}

The authors declare having followed the protocols in use at their working center regarding patient's data publication.

\section{CONFLICTS OF INTEREST}

The authors declare that there are no conflicts of interest.

\section{FUNDING SOURCES}

No subsidies or grants contributed to this work.

\section{REFERENCES}

1. Clark MA, Fisher C, Judson I, Thomas JM. Soft-tissue sarcomas in adults. N Engl J Med. 2005;353:701-11.

2. Mingoli A, Cavallaro A, Sapienza P, Di Marzo L, Feldhaus RJ, Cavallari N. International registry of inferior vena cava leiomyosarcoma: analysis of a world series on 218 patients. Anticancer Res. 1996;16:3201-5.

3. Kieffer E, Alaoui M, Piette JC, Cacoub P, Chiche L. Leiomyosarcoma of the inferior vena cava: experience in 22 cases. Ann Surg. 2006;244:28995.

4. Hartmann JT, Patel S. Recent developments in salvage chemotherapy for patients with metastatic soft tissue sarcoma. Drugs. 2005;65:167-78.

5. Carter NJ, Keam SJ. Trabectedin: a review of its use in soft tissue sarcoma and ovarian cancer. Drugs. 2010;70:355-76.

6. van der Graaf QT, Blay JY, Chawla SP, Kim DW, Bui-Nguyen B, Casali PG, et al. Pazopanib for metastatic soft-tissue sarcoma (PALETTE): a randomised, double-blind, placebo-controlled phase 3 trial. Lancet. 2012;379:1879-86.

7. Demetri GD, Chawla SP, von Mehren M, Ritch P, Baker LH, Blay JY, et al. Efficacy and safety of trabectedin in patients with advanced or metastatic liposarcoma or leiomyosarcoma after failure of prior

anthracyclines and ifosfamide: results of a randomized phase II study of two different schedules. J Clin Oncol. 2009;27:4188-96.

8. Zewail-Foote M, Hurley L. Ecteinascidin 743: A minor groove alkylator that bends DNA toward the major groove. J Med Chem. 1999;42:14937.

9. Demetri GD, von Mehren M, Jones RL, Hensley ML, Schuetze SM, Staddon A, et al. Efficacy and safety of trabectedin or dacarbazine for metastatic liposarcoma or leiomyosarcoma after failure of conventional chemotherapy: results of a phase 3 randomized multicentre clinical trial. J Clin Oncol. 2016 34:786-93.

10. Le Cesne A, Blay J, Domont J, Tresch-Bruneel E, Chevreau C, Bertucci $\mathrm{F}$, et al. Interruption versus continuation of trabectedin in patients with soft-tissue sarcoma (T-DIS): a randomized phase 2 trial. Lancet Oncol. 2015;16:312-9.

11. Schoffski P. Pazopanib in the treatment of soft tissue sarcoma. Expert Rev Anticancer Ther. 2012;12:711-23.

12. Mohindra N, Agulnik M. Targeted therapy and promising novel agents for the treatment of advanced soft tissue sarcomas. Expert Opin Investig Drugs. 2015;24:1409-18. 